UNTAG Law Review (ULREV)

Volume 2, Issue 2, Nov 2018, PP 169-176

ISSN 2549-4910 (online) \& ISSN 2579-5279 (print)

http://jurnal.untagsmg.ac.id/indeks.php/ulrev/indeks

www.fakhukum.untagsmg.ac.id

\title{
VIOLATIONS AND LAW ENFORCEMENT AGAINST MARK VIEWED FROM LAW NO. 20 OF 2016 CONCERNING MARK AND GEOGRAPHICAL INDICATIONS
}

\author{
Bakti Trisnawati \\ Faculty of Law UNTAG Semarang \\ Email : baktitrisnawati@gmail.com
}

\begin{abstract}
Right on marks are a source of material wealth for their owners because they have economic value that can bring high profits. Marks in trade also have dual functions as competition tools and monopoly tools. Therefore, every mark owner needs to register his mark in order to get legal protection. Because in reality everyday there are many violations of the mark even though the mark has been registered, so the registered mark owner feels aggrieved. Violations due to people wanting to make a profit by cutting short the example of a registered and well-known mark, in addition to the Human Resources of the Directorate General of Intellectual Property itself also lacks control over the law on mark, so marks that should be rejected by many are approved. In addition, the Law Enforcement has indeed been implemented, but not maximal. This can be seen from the demands and fines of the Public Prosecutor and the Decision of the Panel of Judges is still very light.
\end{abstract}

Keywords : Violations, Law Enforcement, Marks

\section{INTRODUCTION}

Rights on mark are immaterial wealth that can bring high economic benefits. This can occur when used to market a particular industrial product. High or expensive value is associated with the quality of the product in the eyes of consumers. The high quality of a product is marked by a well-known brand that is attached to its merchandise. Famous marks are intellectual property rights that are a source of material wealth for their owners.

One of the famous brands is Coca Cola. Everywhere people drink Coca Cola, the sales volume of Coca Cola products is increasing. This means more and more profits are obtained. From the national intellectual property seminar held by the Directorate General of Intellectual Property Ministry of Law and Human Rights in Bandar Lampung, it can be seen that the profits obtained by the company that owns the Coca Cola brand in Atlanta, United States, which comes from 
the brand license alone reaches 36 trillion US Dollars.

So intellectual property in this case the rights on marks is a source of material wealth for the owner because it has economic value. In industrial and trade activities, economic benefits cannot only be enjoyed by the owner, but also by other parties. Therefore, brand owners need to get legal protection. Because in everyday reality there are many violations of well-known brands, so the actual brand owners feel aggrieved.

Based on what has been described above, the authors are interested in writing a paper entitled "Violations and Law Enforcement Against Mark Viewed From Law No. 20 of 2016 concerning Mark and Geographical Indications."

\section{FORMULATION OFTHE PROBLEM}

1. What causes violations of rights on marks?

2. What is the law enforcement that will be carried out against a violation of rights on marks?

\section{DISCUSSION}

\section{Causes of violations of rights on marks}

Mark is a part of Intellectual Property which is very close to the trading of goods and/or services. Besides that, the Mark also functions as an identification of a product that is very helpful for consumers in choosing the product of goods and/or services they want. In this case, the mark is used in an item label.

If we look at the meaning of the mark formulated in Article 1 number 1 of the Mark Law No. 20 of 2016:

" Mark means any sign capable of being represented graphically in the form of drawings, logos, names, words, letters, numerals, colors arrangement, in 2 (two) and/or 3 (three) dimensional shape, sounds, holograms, or combination of 2 (two) or more of those elements to distinguish goods and/or services produced by a person or legal entity in trading goods and/or services."

So in principle the mark is an identification of an item or service, where the use of the mark is intended to distinguish the product or service produced by one party with the other party. Here the mark is an individual's individual rights.

As an individual right, the mark is a monopoly right for the owner. In the sense that the mark owner has the right to prohibit other parties from using or using their marks in trading goods and/or services, or giving permission to other parties to use the mark. This method often occurs through a mark license agreement in return for payment of a number of royalties. 
The function of the mark other than being an identity that indicates the origin of the item or service originating from a particular party, the mark also has a function to indicate the quality of goods or services. It is not wrong to say that the mark is closely related to reputation. Building a mark into a brand image for consumer is not easy. This requires a lot of time and money, for example the promotion fee is very expensive.

Marks are also one of the company's assets, in addition to other assets. Through this mark will greatly determine the company's income. Therefore, mark reputation must always be maintained.

When viewed from the history of mark protection law in Indonesia, it has been in existence since 1961. Existing mark protection at that time was still declarative, with the right to mark arising from usage and not registration. This concept is perceived as not providing legal certainty for registered mark owners.

Then in 1992, it was replaced by Law No. 19 of 1992, where the declarative system was replaced by a constitutive system. According to Law No. 19 of 1992 concerning Marks, who registers first, he is entitled to the mark. Means that registered mark owners can use the mark themselves or can give permission to others to use it, even registered mark owners can:

a. Prohibit others from using the same mark, both on the poko and on the whole for similar items.

b. Perform compensation claims.

c. Prosecute criminal law.

Furthermore, in line with the increasing development of national economic activities and in the context of adjustments with the approval of TRIPs which have been ratified by Indonesia, finally the Law No. 19 of 1992 concerning Marks was revised by Law No. 14 of 1997; and in 2001, was replaced by Law No. 15 of 2001 concerning Marks. And 2016 was replaced with the Mark Law No. 20 of 2016. Considering the right to mark constitutes a personal intellectual property of a person, to obtain legal protection, the owner must submit an application for mark registration. As for what is meant by the mark must be rejected if:

a. The mark has similarities in principle or in its entirety with a mark belonging to another party that has already been registered in advance for similar goods and/or services.

b. Have similarities in principle or in whole with well-known marks owned by other parties for similar goods and/ or services.

c. Have the same principal or all with geographical indications for similar goods and/or services. 
d. Have resembles the name of a famous person, photo, mark and name of a legal entity owned by another person who is well known, except with written consent.

e. It is imitation or resembles the name or abbreviation of names, flags, symbols or symbols or emblems of the state or national or international institutions, except with written approval from the competent authority.

f. Is an imitation or resembles an official sign or stamp or stamp used by the state or government agency, except with written approval from the competent authority.

In addition to the mark being unable to be registered or having to be refused from registration as described above, the mark can also be deleted or canceled from the General List of the Mark. Abolition of Mark Registration from the General Register of Marks can be done in two ways, namely:

a. On the initiative of the Directorate General of Intellectual Property, or

b. Based on the request of the relevant mark owner

Of what has been described above, there is a need for legal protection for mark owners. Because legal protection is an effort regulated by law to prevent violations of intellectual property rights by unauthorized people. If a violation occurs, the violator must be legally processed, and if proven to have committed a violation, he will be sentenced in accordance with the provisions of the Mark Law No. 20 of 2016 concerning Marks and Geographical Indications.

Violation of mark rights is basically done as a human action caused by the existence of a relationship between the need to get a profit and a shortcut and easily. The forms of violations of the rights to the mark are in the form of forgery. The occurrence of this violation is seen as not only detrimental to the right owner, but also can harm the public interest, for example detrimental in the field of taxation, consumers and the economy and even harm politically internationally.

From this provision it is clear that a mark cannot be registered and rejected if the owner has bad intentions. A mark owner who has good intentions is the owner who registers properly and honestly without anything to piggyback on, imitating the fame of the other party's mark for the sake of his business which results in loss to other parties or misleading consumers.

But in reality, what happens is that there are serious violations of other people's mark rights in trading a product in the market, both in the domestic and international markets. Cases of imitating a mark or falsifying a mark are examples of violations of an Intellectual Property. 
Based on observations in the field, the causes of mark violations were mostly caused by people wanting their products to sell well like everyone else's work without much effort, so they imitated the famous mark of someone else who happened to have the same production as hers. The same here can be the same in essence or in its entirety with someone else's mark. In addition, it encourages people to violate the rights to marks belonging to other people, this is because human resources in the Directorate General of Intellectual Property of the Ministry of Law and Human Rights lack control over Intellectual Property in terms of receiving registration. Finally, many of the marks that enter the Directorate General of Information Technology, which have the same principal or the whole with the property of others, are all approved and given a certificate.

\section{Law enforcement will be carried out against violations of rights on marks}

If there is a violation of the right to the mark as described above, then the method of law enforcement that can be done is as follows:

a. Investigation Stage

To investigate whether a brand violation has occurred, Article 99 of the Brand Law No.20 of 2016 regulates investigators. According to the contents of the article, in addition to Investigators of the Republic of Indonesia State Police, certain Civil Servants within the Ministry of Justice and Legislation are given special authority as investigators as referred to in the Criminal Procedure Code, to conduct criminal investigations in the Trademark field. The Civil Servants Officer is authorized.

b. Recovery Stage

If there has been a crime of trademark infringement, then the right of the violated party must be restored, both criminal and civil. To restore that right, according to the provisions of Article 100 - Article 102 of the Mark Law No.20 of 2016 concerning Marks and Geographical Indications regulating the perpetrators of crime and Mark violations are prosecuted and threatened with crime.

Law enforcement against Brand violation crimes based on Law No.20 of 2016 concerning Trademarks and Geographical Indications has indeed been carried out on people who commit criminal acts, but law enforcement against Brand forgery is still half or not maximal. This can be seen from the demands and fines of the Public Prosecutor and the Verdict of the Panel of Judges who conduct examinations \& sentences against perpetrators of Brand violations are still very mild, namely imprisonment for 1 (one) year and 6 (six) months and a fine of Rp.2,000,0000 00 (two million rupiah).

Whereas the criminal law enforcement regulation contained in CHAPTER XVIII Criminal 
Provisions Law No.20 of 2016, which is sentenced to a maximum imprisonment of 5 (five) years and/or a fine of a maximum of Rp. 2,000,000,000.00 (two billion rupiah).

In addition to criminal prosecution, a civil lawsuit can be made against Brand violations. This is regulated in Article 83-Article 84 of the Law on Trademarks No.20 of 2016 concerning Trademarks and Geographical Indications. The owner of a registered mark may file a lawsuit against a person or legal entity that without the right to use the mark for goods and/or services that have similarities in its entirety or in principle with the mark.

The lawsuit was filed through the Central Jakarta Commercial Court or other Commercial Courts determined by a presidential decree. A claim for a brand violation can also be filed by a Registered License recipient, either alone or jointly with the relevant Mark owner.

At the request of the trademark owner or the licensee of the registered Mark as the plaintiff, as long as it is still under investigation and to prevent a greater loss, the judge may order the defendant to stop trading in goods or services that use the Mark without such rights. In the event that the defendant is also required to hand over the goods that use the Mark without rights, the judge may order that the delivery of goods or the value of the goods be carried out after the court's decision has permanent legal force and after the plaintiff has paid the price to the defendant.

\section{Closure}

\section{Conclusion}

a. Causes of violations of brand rights

Violations of brand rights are caused by weaknesses in Article 21 of the Mark Law No.20 of 2016 concerning Trademarks and Geographical Indications, namely that there are still many brands that fulfill the elements:

- Have the same principle or the whole with the brand owned by another party that has been registered first.

- Have the same principle or the whole with a well-known brand owned by another party.

However, many of these brands have passed the registration at the Directorate General of Intellectual Property of the Ministry of Law and Human Rights. In addition, there are still other weaknesses, namely the number of brands registered by applicants with bad intentions and the brand is also a complaint offense.

b. Law enforcement carried out against violations of brand rights can be done by:

1) Investigation phase is to investigate whether there has been a crime of brand violation. (Article 99 of Law No. 20 of 2016). 
2) Recovery phase, namely when a brand violation has occurred, the party violated must be recovered, both criminal and civil.

Law enforcement against violations based on Law No.20 of 2016 has indeed been implemented, but law enforcement against Brand violations is still half or not maximal. This can be seen from the demands and fines of the Public Prosecutor and the Decision of the Panel of Judges is still very mild, namely imprisonment for 1 (one) year and 6 (six) months and a fine of Rp. 2,000,0000.00 (two million rupiah). Whereas what is contained in the Criminal Provisions Law No. 20 of 2016, which is sentenced to imprisonment of a maximum of 5 (five) years and/or a fine of a maximum of Rp. 2,000,000,000.00 (two billion rupiah).

\section{Suggestions}

a. To overcome the weaknesses in the Trademark Law No. 20 of 2016 concerning Trademarks and Geographical Indications, which cause violations of the rights to the mark, all human resources in the Directorate General of Intellectual Property and those in the area or Regional Office must have received special education about Intellectual Property. And if there is a brand imitation, it should not wait until the person who feels harmed reports or raises an objection.

b. If there is a violation of the law on the right to mark, law enforcement must be strictly implemented in accordance with the criminal sanctions contained in the Mark Law No.20 of 2016 concerning Marks and Geographical Indications, regardless of who commits the violation.

\section{REFERENCES}

Abdul Kadir Muhammad, Kajian Hukum Ekonomi Hak Kekayaan Intelektual, PT. Citra Aditya Bakti, Bandung, 2001.

Gunawan Suryo Murcitro, Hak Atas Merek dan Perlindungan Hukum Terhadap Persaingan Curang, Makalah dalam rangka forum diskusi tentang merek di Jakarta, 10 Desember 1992

Harsono Adi Sumarto, Hak Milik Intelektual Khususnya Hak Cipta, CV. Akademika Presindo, Jakarta, 1990

Ita Gambiro, Hukum Merek Beserta Peraturan Perundang - Undangan di Bidang Merek, CV. Sebelas Printing, Jakarta, 1995

Muhamad Djumhana, R. Djubaedillah, Hak Milik Intelektual, Sejarah, Teori dan Prakteknya di Indonesia, PT. Citra Aditya Bakti, Bandung, 2003. 
Rachmadi Usman, Hukum Hak Atas Kekayaan Intelektual, Perlindungan dan Dimensi Hukumnya di Indonesia, PT. Alumni, Bandung, 2003

R.M. Suryodiningrat, Hak Milik Perusahaan, Tarsito, Bandung, 1986.

Saidin, Aspek Hukum Hak Kekayaan Intelektual (Intelektual Property Right), PT. Raja Grafindo Persada, Jakarta, 1995.

Sudargo Gautama, Hak Merek, Alumni, Bandung, 1997. ,Undang-Undang Merek Baru,Alumni, Bandung, 1992.

T. Didik Taryadi, Pentingnya Perlindungan Merek Bagi Pembangunan Ekonomi, Direktorat Merek, Direktorat Jenderal HaKI Departemen Kehakiman dan HAM RI, 2004

T. Gilarso, Pengantar Ilmu Ekonomi Bagian Mikro Jilid 2, Kanisius, Yogyakarta, 1993

Tim Lindsey, Eddy D, Simon, Tommy, Hak Kekayaan Intelektual Suatu Pengantar, PT. Alumni, Bandung, 2002

Yahya Harahap, Tinjauan Merek Secara Umum dan Hukum Merek di Indonesia, Penerbit Citra Aditya Bakti, Bandung, 1996

UU RI No. 20 Tahun 2016 tentang Merek, CV Novindo Pustaka Mandiri, Jakarta, 2001 